\title{
シーケンサの最新技術と当社取組み
}

\author{
三菱電機株式会社 ${ }^{* 1}$ 名古屋製作所 FA システム部 堀＼cjkstart誠＼cjkstart司
}

\section{Our Current Efforts to Advance PLC Technology}

Seiji Hori

FA System Dept., Nagoya Works, Mitsubishi Electric Corporation*1

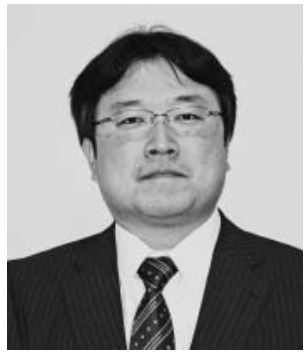

\begin{abstract}
Today's manufacturing industry is expected to further reduce costs and improve production efficiency due to global competition and shortened product life cycles.

To meet these needs, we have improved the performance and reliability of our new products.

We would like to introduce our approach, using PLCs, to reduce the total cost of manufacturing.
\end{abstract}

分類： $V_{1}$ 計装・制御システム一般， $V_{0}$ その他

1.はじめに

今日の製造業では，グローバル競争の激化に伴う製品価 格の下落，製品ライフサイクルの短期化などにより，生産 設備に対するより一層のコストダウンや生産効率化が求め られており, オープン化・マルチベンダ化が可能で, 拡張 性・柔軟性の高いシーケンサへのニーズは増大している。

当社はこのようなニーズに応えるべく，シーケンサの高 機能化, 高性能化, 品揃えの拡充, 信頼性強化等を行い, FA 分野での用途拡大・採用拡大を図ってきた。また, 最 近では生産設備だけに留まらない, 生産現場全体のトー夕 ルコスト削減を実現する仕組みも必要とされており, シー ケンサでもこのような要望を見据えた取組みを行っている。 本稿では, シーケンサシステムの中核をなす CPU, ネ ットワーク，エンジニアリングソフトなどの最新製品及び, ループ制御とシーケンス制御の同時実行が可能な計装シー ケンサを紹介し, 生産現場のコスト削減に向けたシーケン サの取組みについて述べる。

\footnotetext{
${ }^{* 1} \mathbf{T} 461-8670$ 愛知県名古屋市東区矢田南 5-1-14/5-1-14 Yadaminami, Higashi-ku, Nagoya-Shi,Aichi 461-8670, Japan
}

\section{2. シーケンサの動向}

\section{1 シーケンサの進化}

三菱シーケンサは1973 年に誕生の後, 1985 年に MELSEC-A シリーズを発売し, 現在の MELSEC-Q シリ ーズに至る。初代の A シリーズは B 5 サイズであったが, 盤の小型化や装置組み込み等のニーズにより, 現在の $\mathrm{Q}$ シリーズではタバコサイズまで小型化し，生産大規模化・ 複雑化するシステムに対応するための高速化要求により, 処理速度は最新機種では初代 A シリーズ比で約 600 倍に もなっている。

また，シーケンサの高性能化によりシーケンス制御以外 への適用ニーズが高まり, 2002 年には計装用途のプロセ ス CPU，2004 年には高信頼性対応の二重化 CPU を発売 するなど，一般的なシーケンス制御のコントローラからラ インナップを拡大している（図 1)。

最新のユニバーサルモデル CPU の性能を表 1 に示す。 基本命令性能, 浮動小数点演算性能の向上によって, 従来 シーケンサでは対応できなかった高速制御や高速演算が必 要とされる用途への適用が可能となった。また，プログラ ム本数の拡張により，プログラムの部品化・構造化がしや すくなり, プログラム/データメモリ容量の拡大によって, $\mathrm{MES}$ ・ ERP などの情報システムとの連携で必要とされる 生産デー夕，品質デー夕なども十分扱えるようになった。 


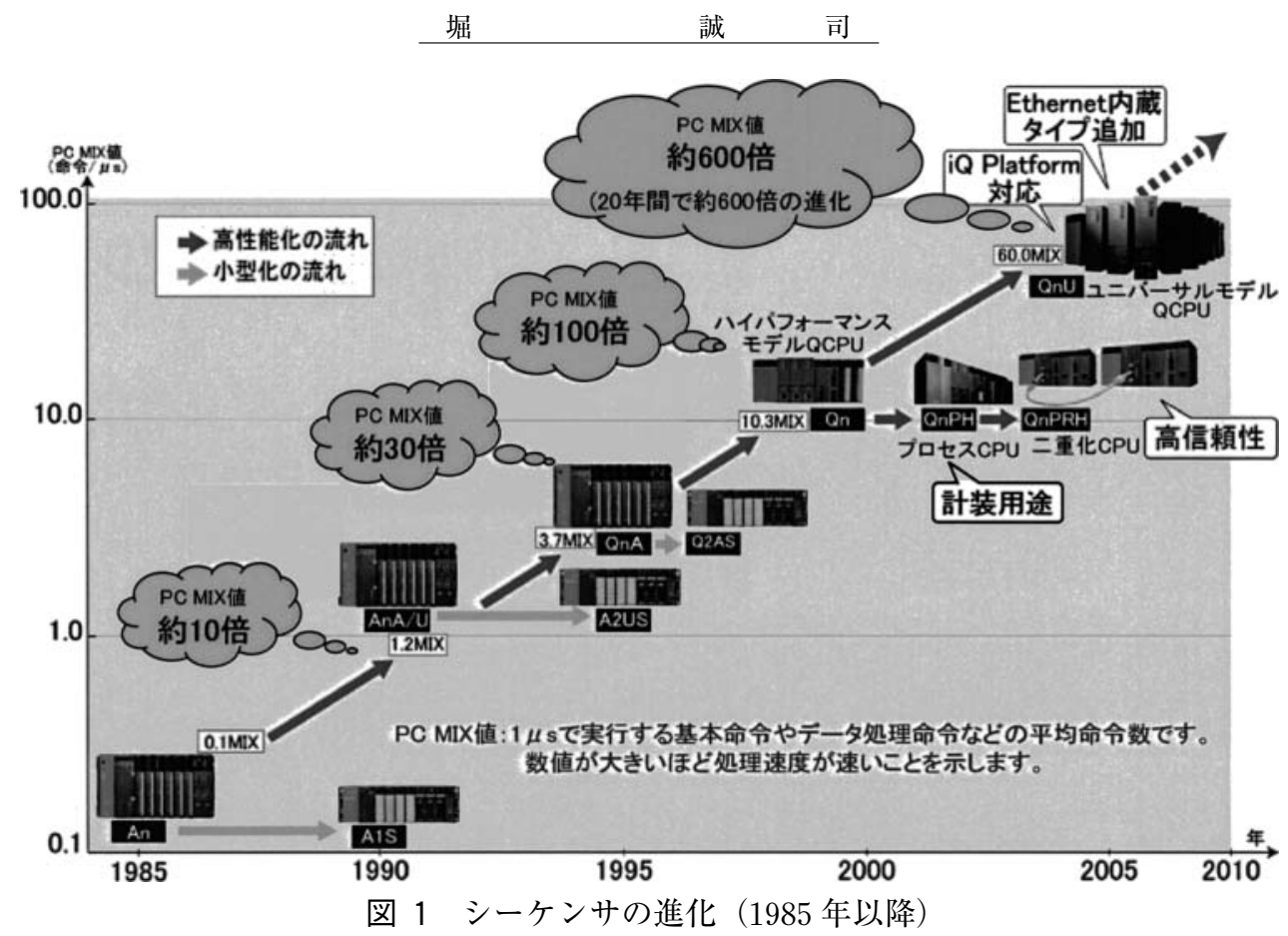

表 1 ユニバーサルモデル CPU の性能

\begin{tabular}{l|l|l}
\hline \multirow{4}{*}{ 高速化 } & 基本命令性能（処理時間） & 最速 $9.5 \mathrm{~ns} /$ 命令 \\
\cline { 2 - 3 } & 浮動小数点演算性能 (単精度加算時) & 最速 $57 \mathrm{~ns} /$ 命令 \\
\cline { 2 - 3 } & PCMIX 值 $(1 \mu \mathrm{s}$ で実行する平均命令数) & 最大 60 命令 $/ \mu \mathrm{s}$ \\
\hline \multirow{4}{*}{ 大容量化 } & プログラム容量 & 最大 $1,000 \mathrm{k}$ ステップ \\
\cline { 2 - 3 } & プログラム本数 & 最大 252 本 \\
\cline { 2 - 3 } & デバイス容量 & 最大 $925 \mathrm{k}$ ワード \\
\cline { 2 - 3 } & 標準 ROM 容量 & 最大 $16 \mathrm{MB}$ \\
\hline
\end{tabular}

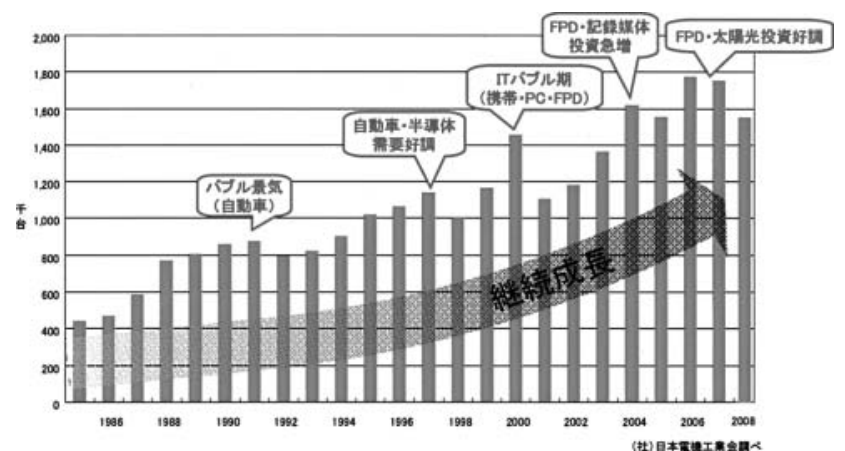

図 2 シーケンサ国内出荷台数推移

\section{2 シーケンサの市場規模}

シーケンサの国内出荷台数推移を図 2 に示す。短期的に はバブル景気などの市況変化の影響は受けているものの, 半導体需要の高まりや, 携帯電話, FPD, 太陽光発電な どへの適用用途拡大, 規模拡大にあわせて長期的には継続 成長しており，1985 年（43万 9 千台）と比較して 4 倍の 伸びとなっていることから, シーケンサは製造業に広く浸 透してきたことがわかる。

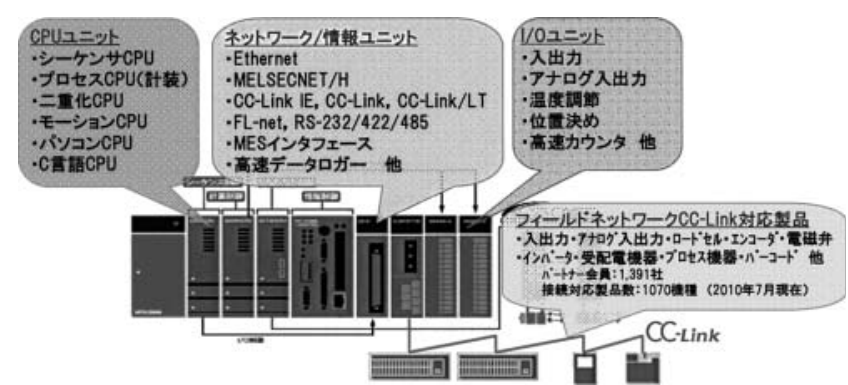

図 3 マルチ CPU システム

今後も，コスト削減要求による専用システムからのダウ ンサイジング，オープン化の流れは継続し， シーケンサの 性能向上による用途拡大も期待されるため, 市場は一定の 成長を継続すると考えられる。

\section{3. 生産現場のコスト削減に向けた取組み}

\section{1 マルチ CPU システム}

MELSEC-Q シーケンサは，一般的なシーケンス制御向 けの CPU 以外にも, 計装用途のプロセス CPUや，モー 


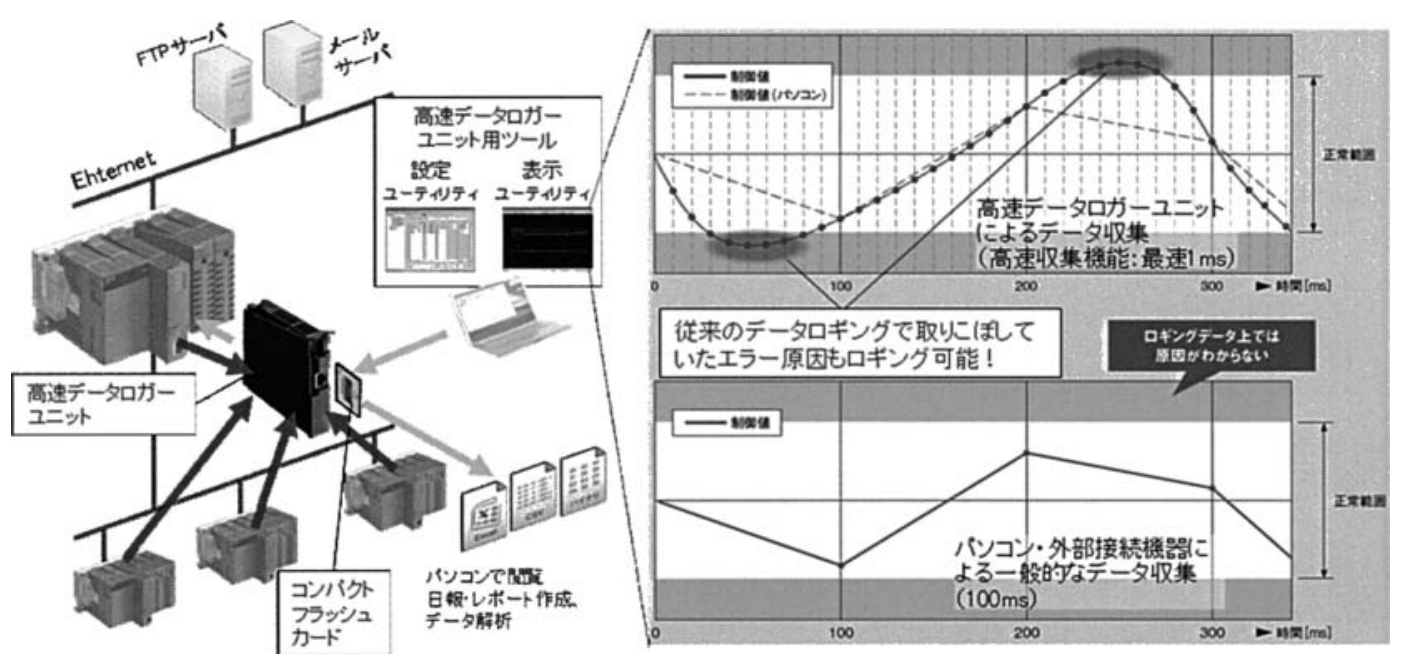

図 4 高速データロガー特長とエラー発生時のデータ収集比較

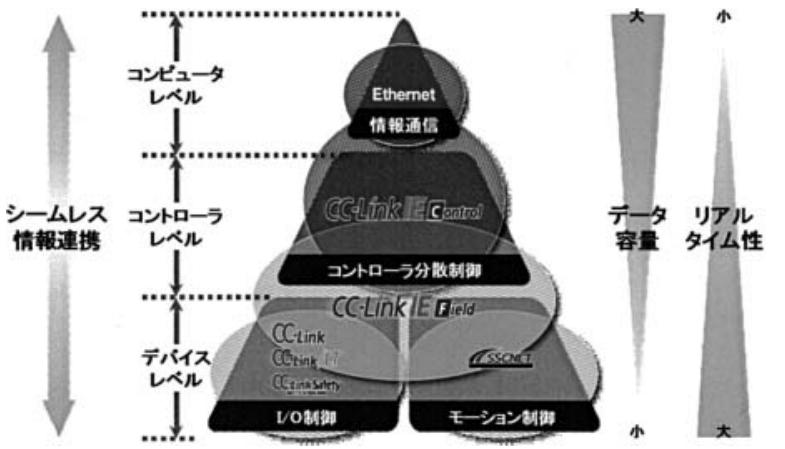

CC-LínkIE Clontrol

高速・大客量, 光二重ルーブによる高信頪のシステムに対えする

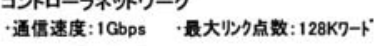

CC-Link IE Field

つのネットワークで高速な、/O制御からコントローラ分敝制御までをがーしし.

機器のレイアウトに合わせた自由度の高い配络性をも实現するネットトワーク

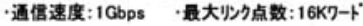

C-Link

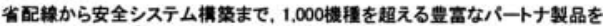

利用できるオーブンフィールドネットワーク

ISSCNET

高速・高信頼の同期型モーションネットワーク

図 5 CC-Link IE 統合ネットワークコンセプト

ション CPU, C 言語 CPU などをラインナップしている。 これらの CPU ユニットはマルチ CPU 構成が可能であり, 同一ベースユニット上に組合せて装着することが可能であ るため（図 3)，同じ CPU を複数台搭載することによる負 荷分散や, 用途にあわせて複数種類の CPU を組合せ, こ れらの CPUを密に結合させることができるのが特長であ る。また，ネットワークユニット， I/O ユニットを共通的 に使用でき省スペースを実現できるなど，規模・目的に応 じた最適なシステムを構築することが可能となる。

\section{2 高速データロガー}

制御対象の大規模化 · 複雑化に伴い, CPU の高速化 · 大容量化が進むと, 生産データや設備特性データ, 設備卜 ラブル解析に必要なデータも密度の高いものが要求される。 高速データロガーは, シーケンススキャンに同期した最速 $1 \mathrm{~ms}$ のデータ収集や, トラブル発生前後のデータを抽出 するトリガロギング機能などの特長を持ち, トラブル発生 時の原因特定を容易にすることができる。

図 4 のグラフはエラー発生時のデータ収集結果を示した 例であるが, 従来のパソコンや外部接続機器による一般的 なデータ収集では取りこぼしていた部分も漏らさずロギン グすることが可能である。

\section{3ＦA 統合ネットワーク CC-Link IE}

生産デー夕, 品質データなどの増加によってシステムが 扱うデータが増大し, CPU 高速化により高速制御が可能

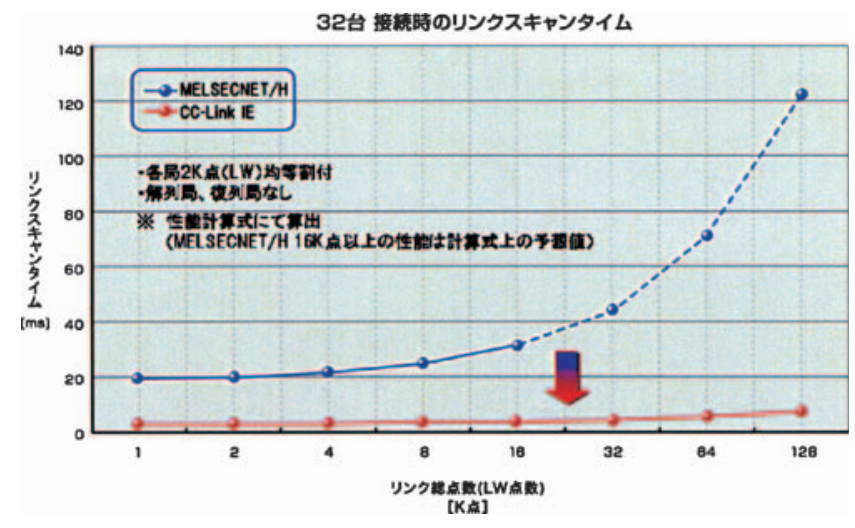

図 6 CC-Link IE Control と MELSECNET/H のリンク スキャンタイム比較

になると，それに伴いネットワークにも大容量化・高速化 が必要となる。

CC-Link IE は，Ethernet 技術ベースによる 1 Gbps（ギ ガビット/秒）の高速通信や，情報系から生産現場にいた るシームレスなデータ伝送などを特長としたネットワーク である。Ethernet 標準のケーブル, コネクタ等の活用や, 簡単立上げによるシステム構築コストの削減, 簡単メンテ ナンスによる運用時のコスト削減を可能としている。CCLink IE には，コントローラレベルの CC-Link IE コント ローラネットワークと, コントローラとデバイスを繋ぐ 


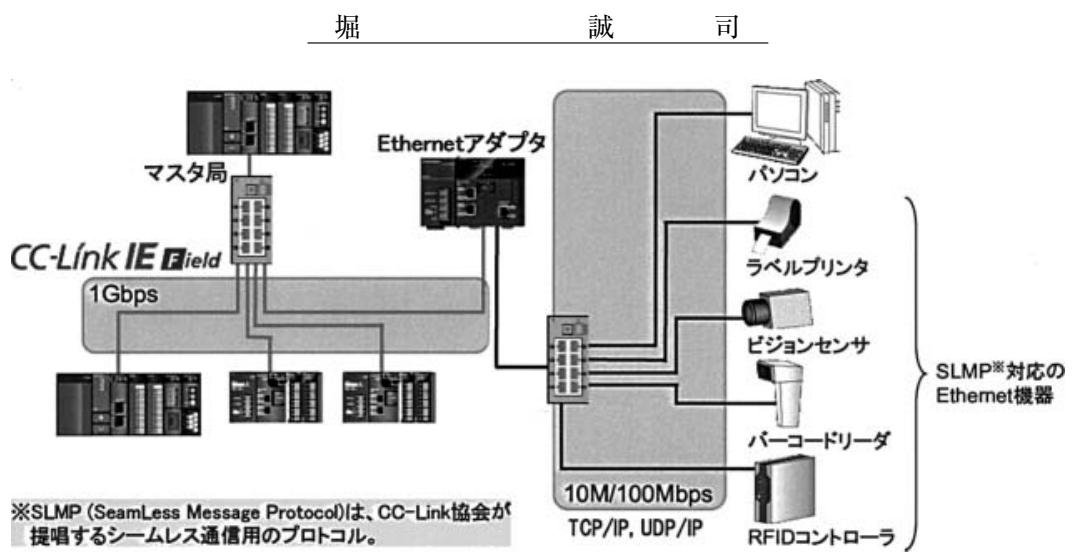

図 7 Ethernetアダプタによる沉用 Ethernet 機器との接続

CC-Link フィールドネットワークの 2 種類のネットワー クがある（図 5)。

図 6 は，CC-Link IE コントローラネットワークのリン クスキャンタイムを示したものである。リンク総点数が増 えても性能の落达みが殆ど無く, 大容量のデータ伝送に十 分対応できることがわかる。

また，CC-Link IE フィールドネットワークでは，ギガ ビット伝送とリアルタイムプロトコルによる高速・大容量 の通信帯域を生かし, コントローラ分散, I/O 制御, モー ション制御の混在構成を可能とする。フィールドデバイス として, 実績のある CC-Link 対応製品が使用できる他, Ethernetアダプタ経由で, ビジョンセンサや, RFIDリー ダライタなどの沉用の Ethernet 機器との接続も可能であ り，システム構築の幅が更に広がる（図 7)。

3.4 FA 統合エンジニアリング環境 $\mathrm{iQ}$ Works

ネットワークが大容量化・高速化し, システムが大規模 化・複雑化するとエンジニアリングコストも増大する傾向 にある。特に，ネットワークによるコントローラ間接続が 増えるにつれて, 複数のコントローラそれぞれにネットワ ークやデバイスのパラメータ設定が必要となり, 作業量が

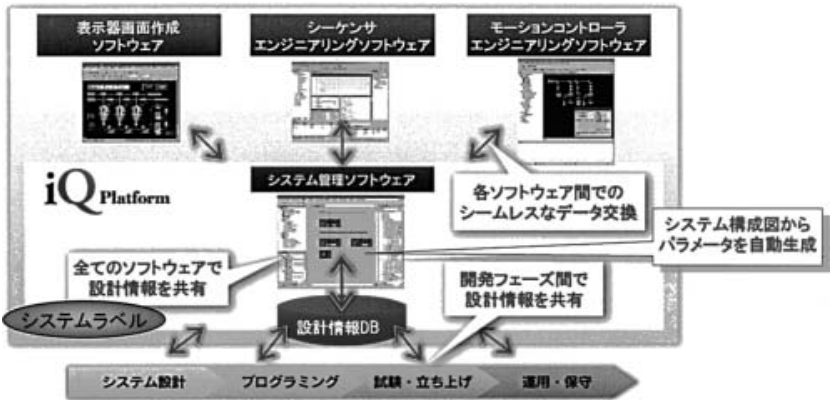

図 8 MELSOFT iQ Works の構成と特長

単純に増大するばかりか, 設定ミスを引起す可能性も増え, 結果的に装置の立上げ作業やデバッグ作業などの作業工 数・コストが増加することとなる。

生産設備導入に関わる全コストに占めるエンジニアリン グコストの割合は大きく，コスト削減を実現するためには， 開発作業者の生産効率向上やミス削減を実現するエンジニ アリングソフトウェアが必須である。

MELSOFT iQ Works は, 表示器, シーケンサ, モーシ ヨンコントローラの各エンジニアリングソフトの機能を,

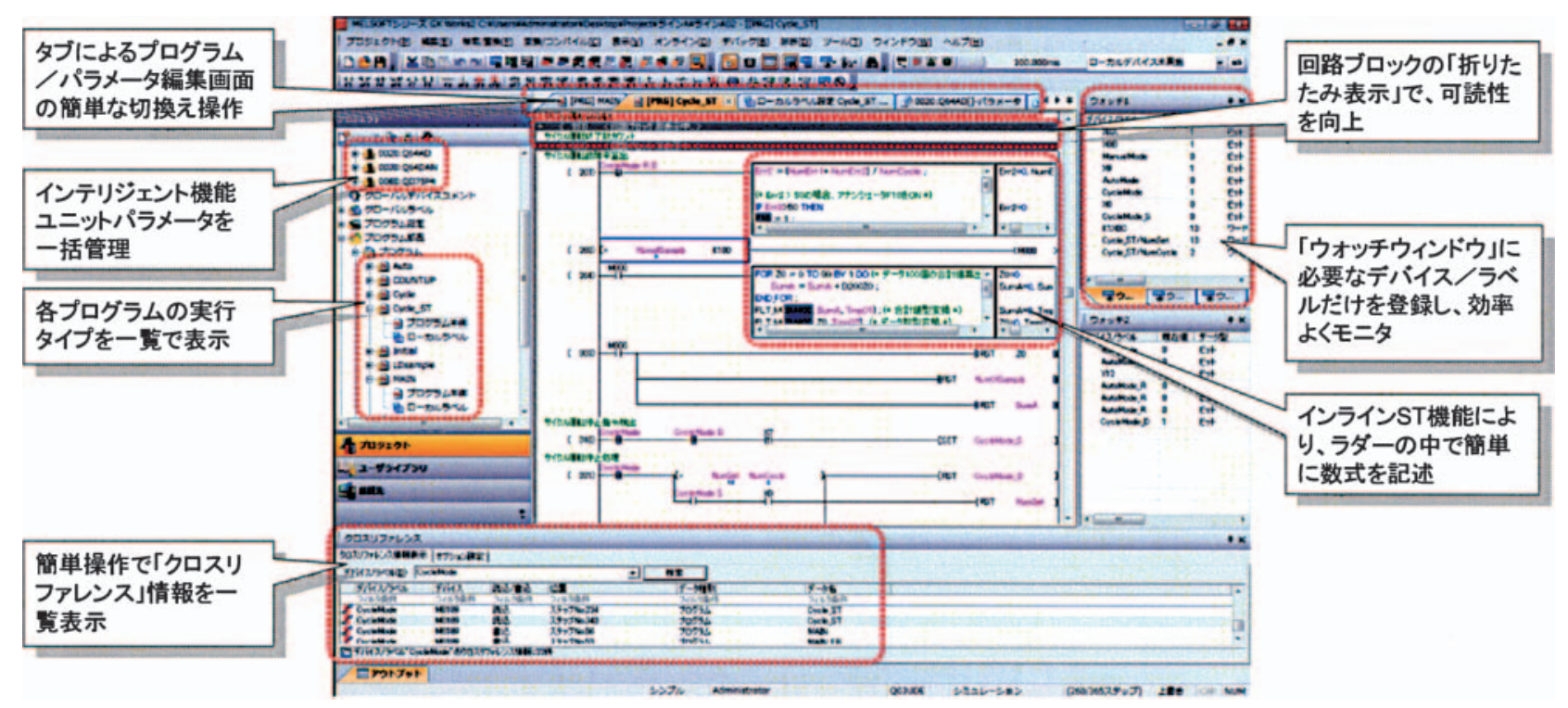

図 9 GX Works 2 のユーザインタフェースの特長 

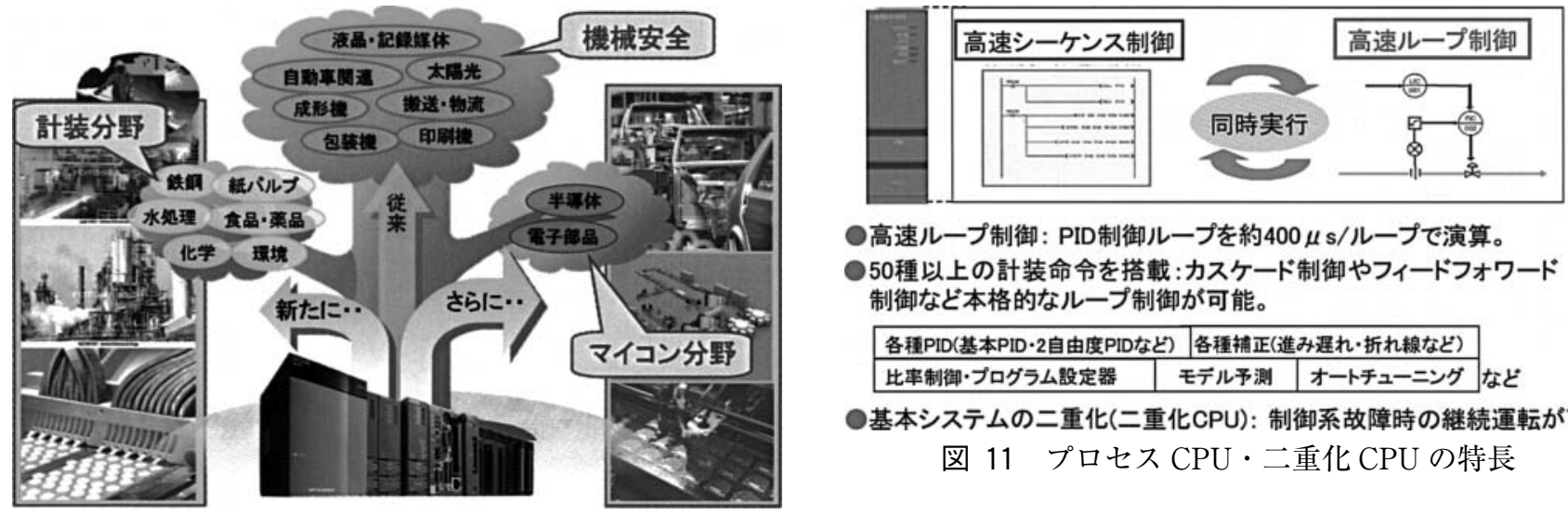

高速ループ制御: PID制御ループを約 $400 \mu \mathrm{s} /$ ループで演算。

○50種以上の計装命令を搭載: カスケード制御やフィードフォワード 制御など本格的なループ制御が可能。

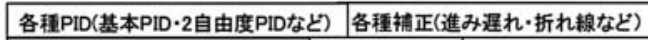 \\ \begin{tabular}{|l|l|l|l} 
比率制御・プログラム設定器 & モデル予测 & オートチューニング など
\end{tabular}}

○基本システムの二重化(二重化CPU): 制御系故障時の継続運転が可能

図 11 プロセス $\mathrm{CPU}$ 二重化 $\mathrm{CPU}$ の特長

図 10 シーケンサの新分野への展開

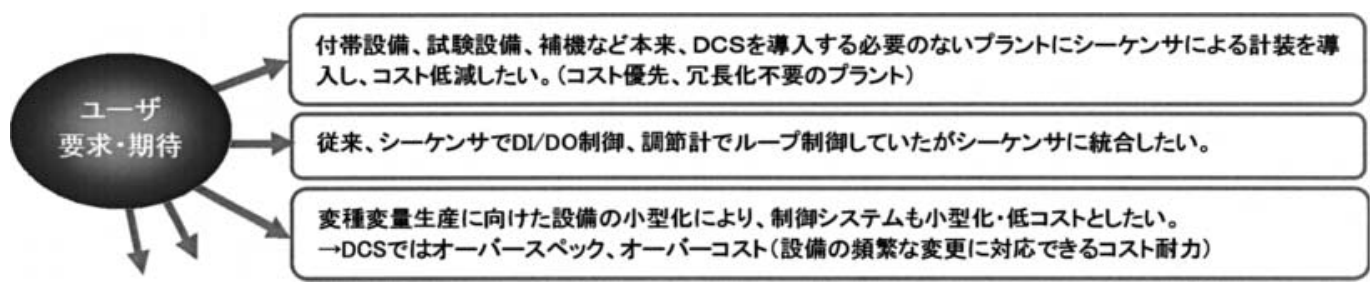

図 12 計装シーケンサに対する期待
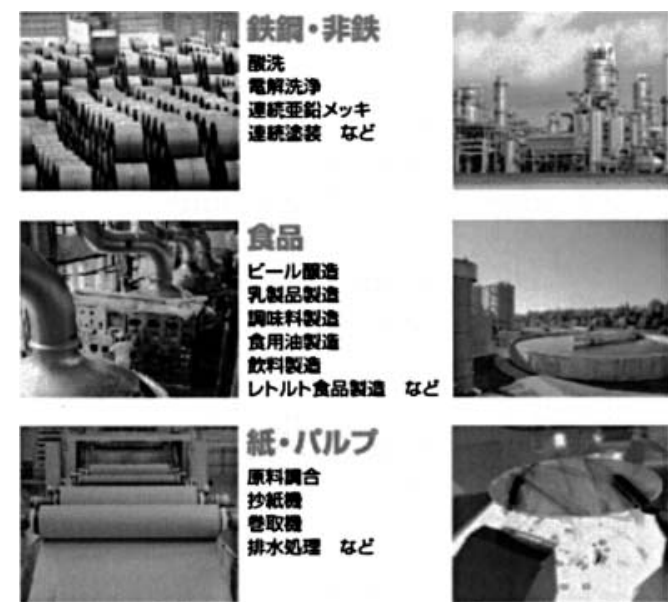

緍・バルブ

国和明合

Mute

取整

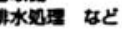
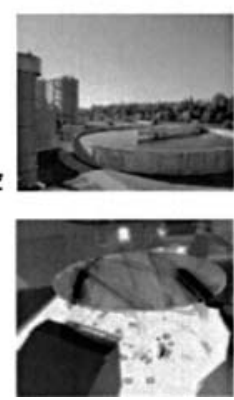

図 13 計装シーケンサの適用実績

水迈理

上下水边温

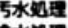

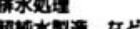

半裂体

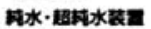

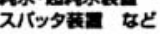

化学

フラスチック・各战コム

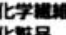

化船品.

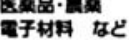

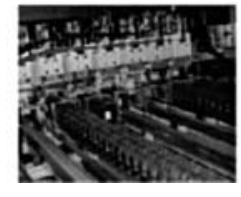

斯境・新エネ

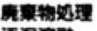

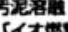

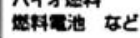

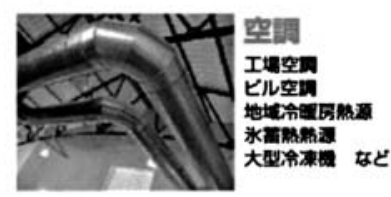

\section{織械}

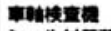

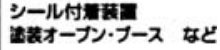

システム管理ソフトウェアを中心に相互に利用・連携でき る仕組みを実現し，開発効率化を図っている（図 8)。

システム管理ソフトウェアは，システムを構成するユニ ット構成とネットワーク構成を, 一覧からのドラッグ\&ド ロップ操作によりグラフィカルに作成できるようになって いる。その際，システム構成からユニットのパラメータが 自動生成されるため，手間やミスを削減できる。また，各 エンジニアリングソフト間で共通して使用可能なシステム ラベルを定義することで，デバイスアドレスや複雑な機器 接続の設定を意識する必要が無くなることから，プログラ ミングや作画作業に集中することができる。

また，シーケンサエンジニアリングソフトウェア GX Works 2 では, 従来の GX Developer のプログラム資産や 操作性を継承しながら，ユーザインタフェース刷新による
使い勝手の大幅な向上や，インライン ST 機能，プログラ ム履歴管理機能などの機能追加による設計効率向上を図っ ている（図 9）。

\section{4. 新しい分野への展開}

このように，生産現場のコスト削減に向けた取組みを行 っているシーケンサであるが，自動車関連，搬送・物流な どの従来の FA 分野以外にも, 計装分野への展開，さらに は，機械安全，マイコン分野への展開も進んでいる（図 10）。ここでは, FA 分野以外へ展開の一つである，計装 分野へのシーケンサの適用について述べる。

4.1 計装分野への適用

シーケンサをベースとした計装用途のプロセス CPU は, シーケンサの特長である高速シーケンス制御と，高速ルー 
プ制御の同時実行（EI 統合制御）を特長（図 11）として いる。また, 二重化 CPU は, EI 統合制御に加え, CPU ユニット, 電源ユニット, 基本ベースユニット, ネットワ ークユニットの基本システムの二重化により, 制御動作中 のユニット（制御系）が故障しても, 自動的に待機系に切 替ることで継続運転が可能である。更に, 故障した系はユ ニット単体，もしくは基本システムごと交換できるため迅 速な復帰が可能であるなど, システムの信頼性・メンテナ ンス性を向上している。

これら計装用途のシーケンサ（計装シーケンサ）は，付 帯設備・試験設備などの DCS ではオーバースペックとな るような設備のコストダウンや, シーケンサと調節計の組 合せをシーケンサに統合したいといったユーザの期待（図 12）にマッチし, 鉄鋼, 化学, 環境, 水处理, 紙パルプ, 食品・薬品等の業種において活用されている（図 13）。ま た, 例えば上下水道などの, 公共性が高くシステム停止の 影響が大きいなどの高信頼性が要求される分野については 二重化 CPU も多く採用されている。

今後，1980 年代～ 90 年代前半に導入された DCS が次々 に更新時期を迎えることから, 計装シーケンサ需要の高ま りが期待される。

\section{2 計装シーケンサのコスト削減に向けた取組み}

計装シーケンサ導入時のコストを考えると，ハードウェ アコストが安価であるのに対して, エンジニアリングコス トが占める割合は大きく, コスト削減のためにはエンジニ アリングコストの削減が重要となる。

当社の計装制御用エンジニアリングソフトである $\mathrm{PX}$ Developerは, ループ制御に必要十分な FB（ファンクシ ヨン・ブロック）やファンクションを多数標準搭載してお り，これら FB やファンクションを画面上に貼付け，結線 し, PID 定数や上下限值などのパラメータを設定するだけ の簡単プログラミングでループ制御を実現できる（図 14）。

また, 計装シーケンサは付帯設備・試験設備での導入が 多いこともあり, 装置の制御盤面やプロセスラインの現場

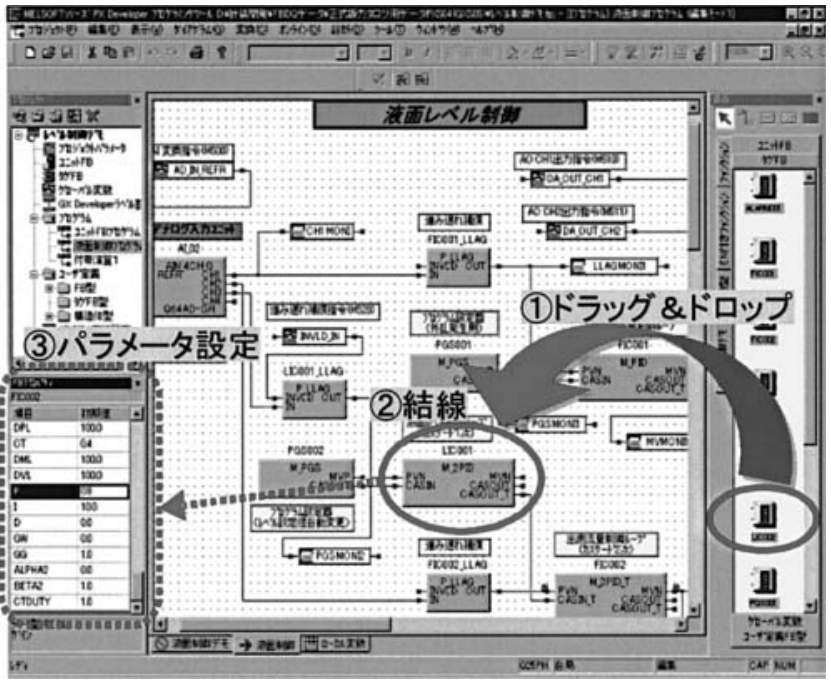

図 14 PX Developer によるプログラミング

端末での監視操作用途としての表示器との組合せが非常に 多い。この表示器の画面作成には手間が多く発生するため, 画面作成工数の削減がエンジニアリングコスト削減に直結 する。

表示器用の画面には, グラフィック画面, フェースプレ ート, トレンド画面, チューニング画面，アラーム一覧な どがあるが, PX Developer では, 図 15 に示す表示器 (GOT 1000）用の画面を自動生成することで，ユーザによる画面 作成の手間を削減することができる。

さらに, 中央監視操作に用いられるSCADAについて は，市販 SCADA と PX Developer との機能連携を実現し ており, フェースプレート部品の提供, タグ連携機能, ア ラーム統合機能等によるエンジニアリング工数削減への取 組みを行っている。その他にも，プログラム作成コスト削 減に向けた, PX Developerの使い勝手の向上, 機能追加 の取り組みも日々行っている。

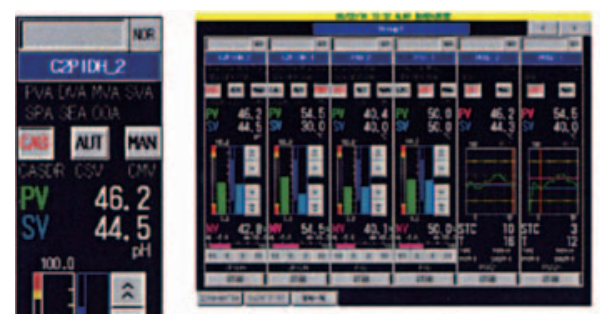

コントロールパネル

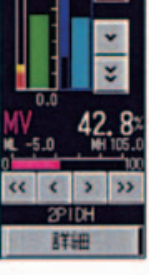

フェース

プレート

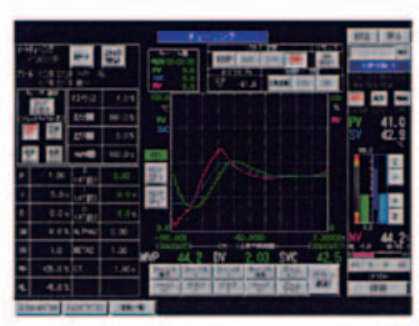

チューニング画面

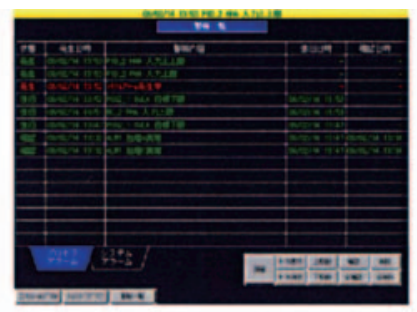

警報一覧画面

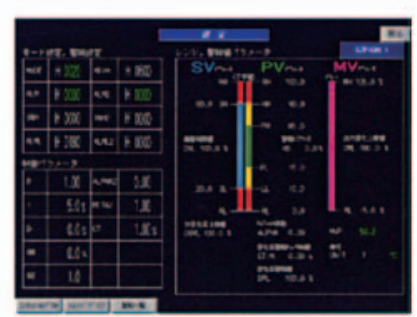

タグ項目設定画面

図 15 表示器用の標準画面

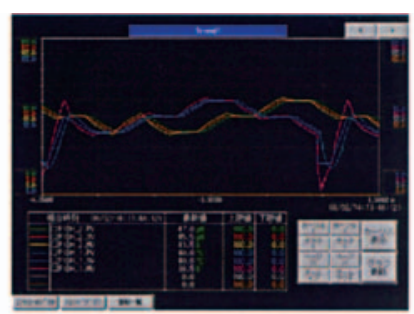

トレンドグラフ画面

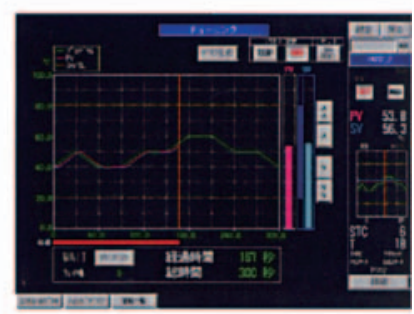

プログラム設定器画面 


\section{5. おわりに}

本稿では，生産現場のコスト削減に向けたシーケンサの 取組みとして，シーケンサの中核をなす $\mathrm{CPU}$ ，ネットワ ーク，エンジニアリングソフトなどの最新技術と, シーケ ンサの FA 分野以外への展開例として, 計装シーケンサを 紹介した。

今後も，グローバル競争などの製造業を取り巻く環境は， 厳しさを増すことが予想され，益々のコスト削減，生産効
率化への要求が予想されるものと思われる。

三菱電機では，生産設備だけでなく，ERP・MESなど の上位情報システムとの連携により工場内の情報を一元管 理し, 工場全体の見える化による生産性向上を実現する, 三菱 FA 統合ソリューション $\mathrm{e}-\mathrm{F} @$ ctory を推進しており， その核となるシーケンサの進化は不可欠である。今後も, シーケンサの高性能化, 品揃え拡充, 利便性の向上など, 生産現場のトータルコスト削減に向けた取組みを継続して wく。 